\title{
ФЕНОМЕН ИДЕНТИЧНОСТИ В ТРАКТОВКЕ ПОЛЯ РИКЁРА
}

\begin{abstract}
Аннотация. Можно полагать, что понятие идентичности за последние десятилетия стало весвма востребованным. После работ 3. Фрейда и Э. Эриксона это слово прочно вошло в арсенал различных гуманитарных наук. Сегодня пишут об индивидуальной, социальной, культурной, религиозной самотождественности, о распаде и кризисе идентичности. В статье отмечено, что П. Рикёру удалось дать новую трактовку этому понятию. Он показал, что внутренняя и внешняя идентичность не находятся в простой связи. Здесь обнаруживает себя сложная диалектика. Франиузский философ откликнулся на концепцию профессора Оксфордовского университета Питера Стросона. Он предложил новое решение давней психобизической проблемы, поскольку ввел иное понятие тичности. Данное понятие выступает как базисное - первичное, далее неразложимое. Отождествление атрибутов личности (состояний сознания и тела) возможно только через предществующее образы личности, которой они принадлежат. В результате традиционных для аналитиков поисков исходных состояний анализа - базисных партикулярий - Стросон пришел к выводу, что существуют два типа базисных партикулярий: материальные тела и личности. Не случайно феномен личности занимает значительное место в философско-антропологических размышлениях Рикёра.
\end{abstract}

Ключевые слова: психология, идентичность, диалектика, аналогия, суббект, самотождественность, подлинность, инаковость, императивы культуры, парадокс.

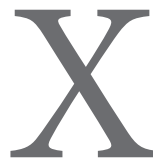

од размышлений об этом феномене, как правило, связан с известным суждением К. Маркса: «Лишь отнесясь к человеку Павлу как к себе подобному, человек Петр начинает относиться к самому себе как к человеку» ${ }^{1}$. Отсюда следует представление о том, что в качестве общественного существа, человек создает устойчивый образ самого себя через социальные связи. Именно общественные отношения помогают ему кристаллизовать свой внутренний мир.

Однако П. Рикёру удалось показать глубинную сложность этой проблемы. Он раскрыл диалектику отношения между двумя видами идентичности. Связь между индивидуальной и социальной самотождественностью оказалась не столь простой. Идентичность не может быть только постоянной или только изменчи-

1 Маркс К., Энгельс Ф. Соч. Т. 23. С. 338. вой. В одном случае можно говорить о внутреннем образе самого себя. А другом - о социальной самотождественности. При использовании понятия обычно смешиваются два значения идентичности - неподвижной идентичностью idem, самотождественного, и подвижной идентичностью ipse, рассматриваемой в ее исторической обусловленности.

Самопознание не может черпать содержание только в изолированном мире своей субъективности. Она одновременно ищет ориентиры в социальных отношениях, в мире культуры. Понятное дело, что эти два вектора идентичности не совпадают, на что и обратил внимание в свое время П. Рикёр. В первом случае субъект отвлекается от всяческих аналогий, он ищет опору в достоверностях своего внутреннего мира. Во втором случае идентичность как процесс как раз предполагает корректировку этого внутреннего образа, в предельном варианте даже приспособление к императивам культуры. Эти два вектора не находятся

Статья подготовлена при поддержке гранта РГНФ № 11-03-00599а «Проблема идентичности в современной культуре» 


\section{Психология и психотехника 5(56) • 2013}

в состоянии гармонии, напротив, им присущ характер противоречия и даже парадокса.

«Вступая в общество, - отмечал А. Шопенгауэр - нам приходится отрекаться от 3/4 своего «я», чтобы сравниться с другими» ${ }^{2}$. Здесь предполагается внутренняя скоординированность, даже замкнутость идентичности как таковой. Но первому смыслу слова «идентичный» в значительной степени противоречит второй, который подразумевает «крайне сходный, аналогичный». В первом случае речь идет о внутренней идентичности, во втором - о внешней, рожденной по сравнению с другими. По этому поводу М. Бахтин писал: «Человек никогда не найдет всей полноты в себе самом» ${ }^{3}$.

Рикёр устанавливает принципиальное различие между методикой определения идентичности человека и идентичности вещи (а также и животного). Все сущее, что есть на земле, хочет быть самим собой. Камень не испытывает желания превратиться в растение. Это, впрочем, мысль Б. Спинозы. Тигр мечтает остаться тигром в той же мере, как муравей муравьем. Естественно, это относится и к человеку. Однако здесь проступает серьезная проблема. Человек в силу своей необычности в природном царстве способен мечтать о возвращении в природу, отказывая себе в сознании, духовности, неповторимости. И тем не менее это проблема идентичности и сохранения устойчивости социокультурных систем, которая как будто беспокоит исследователя.

Человек обретает подлинную идентичность только в том случае, если включает в себя духовный опыт, сталкивается со значимой социокультурной ценностью. Базовая установка экзистенциализма заключается в том, что человек, стремящийся к идентичности, никогда не достигает самотождественности. На этом пути возникают огромные сложности. Вот о них и говорит П. Рикёр. Если вести речь о внутренней идентичности, то она предполагает уникальность, незаместимость личности. Но погружая человека в социальные отношения, мы фиксируем другую сторону проблемы. Здесь обозначается не то, что самостийно, а то, что встречается в других людях. Тогда это слово, скорее всего, выражает представление о другом, аналогичном, сходном.

«Парадокс состоит в том, что мышление имеет дело с понятием идентичности, в котором смешиваются два значения: с самим собой (самости) и идентичности как того же самого. Во втором смысле слово «идентичный» означает то, о чем мы только что упоминали: крайне

\footnotetext{
2 Шопенгауэр А. Афоризма житейской мудрости. М., 1989. C. 10 .

3 Бахтин М.М. Проблемы поэтики Достоевского. М., 1979.
} C. 208 . сходный, аналогичный» ${ }^{4}$. Но как разглядеть того же самого в другом человеке? Каким образом «само» могло бы оставаться подобным, аналогичным в самом предельном варианте, если бы его внутреннее ядро не было постоянным, укорененным, не сохраняло бы в себе некую нерастворимую основу, которая не подвластна временным изменениям?

Допустим, некая личность обрела внутреннюю самодостаточность, прочность. Но внутренний опыт постоянно подвергается трансформациям. Однако если мы хотим обозначить жизненный путь человека - от рождения до смерти, мы понимаем, что, несмотря на неизбежные преображения, индивид все же сохраняет некую канву, основу, которая не подвергается существенным изменениям. В частности, Ж. Лакан отмечал, что в психике человека есть такой пласт бессознательного, который формируется в раннем детстве и затем обнаруживает стойкость, прочность. Этот слой, который французский психоаналитик назвал реальным, не позволяет себе проникнуть в сферу сознания.

И снова мы, обдумывая это противоречие, понимаем, что не только физическая и духовная практика человека раскалывает это ядро и как бы отвергает эту идею самости. «Данная антиномия, - пишет П. Рикёр, - оказывается не только неизбежной, но в равной степени и неразрешимой из-за способа ее формирования, а именно по той причине, что при этом используются категории, несовместимые с понятием жизненной связи» 5 .

Здесь Рикёр обращается к проблеме, которую Кант назвал «категориями отношения». На первом месте находится категория субстанции, схемой которой является «постоянство реального во времени, то есть, по определению Канта, представление о нем как о субстрате эмпирического определения времени вообще, который, следовательно, сохраняется, тогда как все остальное меняется» ${ }^{6}$. Если полагать, что человек сохраняет свою идентичность, то возникает вопрос, а как влияют на него общественные процессы? Или иначе: «как вообще происходит соединение постоянства и непостоянства, без которого невозможна жизненная связь? Рикёр, в частности, ссылается на образ Эммы Бовари. Допустим, некто стремится подражать этой женщине, которая отдается своим чувствам и приносит страдания другим людям. Это отождествление может принять множество форм, начиная с ловушки рабского подражания, как у Эммы Бовари и других с состояний -

\footnotetext{
4 См.: Поль Рикёр в Москве. М., 2013. С. 62.

Там же. С. 62.

Кант И. Критика чистого разума // Соч.: в 6 т. М., 1994.
} T. 3. C. 225. 


\section{Колонка главного редактора}

очарованности, подозрения, отвержения. Здесь возможны, считает Рикёр, самые соблазнительные формы идентификации.

Если вести речь о первом типе идентичности, то есть об уникальности человека, то здесь обнаружатся черты постоянства. Они обусловлены генетическим кодом и запечатлеваются в отпечатках пальцев, а также во внешнем виде, голосе, поведении. Мы можем иметь в виду здесь привычки человека и даже случайные признаки, позволяющие узнать человека, скажем, долговязость Дон-Кихота или большого рубца у Одиссея. Но вот мы включаем индивида в социальные связи, и тогда возникают самые различные социальные маски. Образ убегает от прототипа. Именно поэтому вопрос о личной идентичности оказывается запутанным, загадочным. Никому не дано раскрыть внутреннее ядро своей личности. Казалось бы, чего проще? Повторим за Иосифом Бродским: «Что, в сущности, и есть автопортрет - шаг в сторону от собственного тела». Но как сделать этот шаг? Нас одолевают различные страсти, мы сотканы из коллизий. Человек стремится удержать собственный образ. Он постоянно возвращается к вопросу: «кто я?». Таким образом, то, что не удается идентифицировать, оказывается просто неназываемым. «Самость, - согласно Рикёру, - полностью исчезает лишь тогда, когда персонаж уклоняется от всякой проблематики этической идентичности в смысле способности считать себя ответственным за свои действия» ${ }^{7}$.

Итак, в процессе самоопределения человек колеблется между двумя полюсами - самотождественностью и самостью, подлинностью и инаковости. Вопрос об идентичности имеет, стало быть, два аспекта - частный и публичный. Всякая история жизни смешивается с историями других жизней. Власть способна манипулировать непрочными идентичностями. А соблазн поменять личную идентичность на публичную оказывается взрывоопасной. Онтологическому созиданию личности внутренне присуща диалектика одинаковости и самости.

\section{Список литературь:}

1. Бахтин М.М. Проблемы поэтики Достоевского. М., 1979.

2. Вдовина И.С. Поль Рикёр: герменевтический подход к истории философии // Поль Рикёр в Москве. М., 2013. С. 162-163.

3. уревич П.С. Приключения имиджа. М., 1991.

4. Кант И. Критика чистого разума // Соч.: в 6 т. М., 1994. Т. 3.

5. Рикёр П. Путь признания: три очерка. М., 2010.

6. Поль Рикёр в Москве. М., 2013.

7. Шопенгауэр А. Афоризма житейской мудрости. М., 1989.

\section{References (transliteration):}

1. Bahtin M.M. Problemy poetiki Dostoevskogo. M., 1979.

2. Vdovina I.S. Pol' Riker: germenevticheskiy podhod k istorii filosofii // Pol' Riker v Moskve. M., 2013. S. 162-163.

3. Gurevich P.S. Priklyucheniya imidzha. M., 1991.

4. Kant I. Kritika chistogo razuma // Sochineniya: V 6-i t. M., 1994. T. 3.

5. Riker P. Put' priznaniya: tri ocherka. M., 2010.

6. Pol' Riker v Moskve. M., 2013.

7. Shopengauer A. Aforizma zhiteyskoy mudrosti. M., 1989.

7 Рикёр П. Путь признания: три очерка. М., 2010. С. 100. 